\title{
Local Residents' Perception about Potential Components of Community Based Tourism in Chamoli District of Garhwal Himalaya
}

\author{
Visha Sharma and Anita Rudola \\ Department of Geography, H.N.B. Central University, Srinagar, Garhwal, Uttarakhand \\ *Corresponding Author Email: vashishtha.visha88@gmail.com
}

Received: 16. 09. 2019; Revised: 25.11.2019; Accepted: 6.12.2019

(C) Society for Himalayan Action Research and Development

\begin{abstract}
Chamoli district is the land of various natural and cultural tourism spots and well known for Badrinath (one from the four Dhams) heritage, craft and tremendous natural beauty. Chamoli has the possession on various snow-capped lofty mountain peaks which attracts the tourists and endow with natural splendor. Visitors can get pleasure from culture, customs, costumes, cuisines, dialects and music in the form of community-based tourism as Chamoli is blessed with tremendous culture. This study assesses the perception of local residents about potential components to develop community-based tourism (CBT) in Chamoli district. The qualitative and quantitative technique has been used to collect the data. The results found that perception of communities, for the fact of traditions, uniqueness, and handling of tourism products is a bit negative but overall perception is positive that is very helpful and important to develop as well as enhance CBT in Chamoli district.
\end{abstract}

Key words- Community based tourism, Potential, Culture, Components

\section{Introduction}

Tourism is the most rapidly growing industries worldwide. According to the World Tourism Organization, international tourism is growing at a rate of approximately $4 \%$ per year WTO (2000). As a result of the environmental concern, dissatisfaction is emerging for the mass tourism among the people which led to an increase demand of rural tourism. According to Honey (2008), Community-based tourism is a safe means of earning livelihood through a less destructive use of local resources. Rural areas, which are culturally and traditionally rich, are the main centers of community-based tourism (Mallya, 2006). These days, CBT is essential for the sustainable development as well as it strengthens the local economy. In reference of India, it is said that the country has not reached at par with the neighboring countries (Hai \& Chik, 2011). Pilgrimage tourism in Chamoli District attracts more tourists rather than the other forms of tourism. Though, it has vast potential to attract visitors of every form and be a significant source of earning of the associated population (Gupta \& Bhatt, 2015). In the field of community based tourism, researches revealed that only a very small population is concerned to this form of tourism and the reason behind it is the seasonal tourism activities in this area. However, governments as well as local agencies are working to promote the community based tourism. It is very helpful to conserve and sustain the local resources with the growth of local economy. With the enhancement of the economy there is a need of the planned tourism so that it brings other benefits for the communities (Haque \& Aich, 2014).

The present study acknowledges the fact that identifying local community's perceptions about the components which support the CBT in the area and enhance the quality of the tourism products. Hence, the results of the present study may be used to reorganize the tourism products and simulate the model for tourism growth (Folke et al., 2002; Walker et al., 2002). The residents' perceptions of recreational 
benefits can also provide a good basis for the planning and management of community-based tourism in the Chamoli district.

\section{Area of study}

Chamoli is the second largest district of the Uttarakhand. It is laid between North Latitude $29^{\circ} 02^{\prime} 00^{\prime \prime}$ and $81^{\circ} 03^{\prime} 45^{\prime \prime}$ and East Longitude $79^{\circ} 02{ }^{\prime} 39^{\prime \prime} \& 80^{\circ} 03^{\prime} 29^{\prime \prime}$. The total area of the district is $7520 \mathrm{sq} \mathrm{km}$. It is bound by the Tibet region to the north, by Pithoragarh and Bageshwar districts to the east, Almora to the south \& Tehri Garhwal to the south west, Rudraprayag to the west and Uttarkashi to north-west. The administrative headquarter of the district is Gopeshwar.

The entire area is mountainous and the elevation of the district range from 800 to 8000 masl. There is a lot of potential for community-based tourism in Chamoli district because the host community are continuously involved in providing the tourism related services i.e. eateries, accommodation, transportation, pony rides etc.

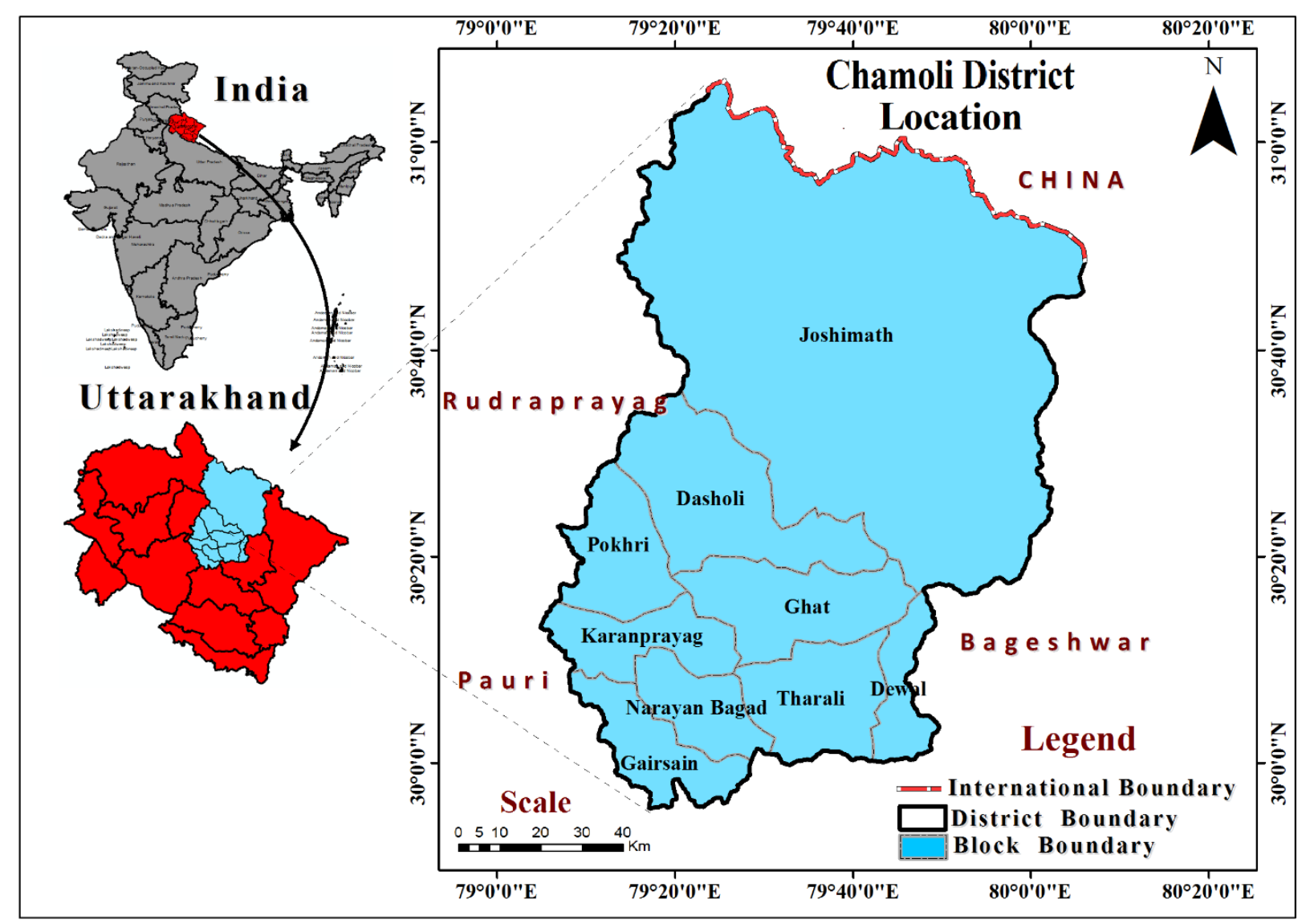

Figure 1: Geographical Location of Chamoli District

\section{Objectives}

The main aim of present study is to find out the potential components of community-based tourism in Chamoli district.

\section{Research methodology}

Present communication is completely based on the primary data. A self-made questionnaire was used for data collection using random sample technique from 31 villages of Chamoli district. Respondents were asked questions about the components that support CBT development. The whole data related with the 
respondent's perception was collected on five-point Likert scale ( $1=\mathrm{SD}$ to $5=\mathrm{SA}$ ). The sample size was 620 respondents. Perception of the respondents has been shown through frequency moreover ranking has been given to every component on the mean basis. Entire data has been analyzed through MS-Excel. Tables \& diagrams have been used to make the data presentable.

\section{Results and Discussion}

The potential components for CBT which are helpful to develop community-based tourism is presented in Table 1. It shows the perception of local community about potential components. These components are pointed out the sense of guest respect, attraction, tradition and customs of local people, hygiene of the destination, home stay, tourist overall experience at a destination. This is 620 respondents' data and the result is based on their perception.

Table No. 1: Potential Components for Community-Based Tourism

\begin{tabular}{|c|c|c|c|c|c|c|c|}
\hline \multicolumn{8}{|c|}{ Potential Components For Community Based Tourism } \\
\hline S.N. & Statements & $\begin{array}{l}\text { S.A. } \\
\%\end{array}$ & $\begin{array}{l}\text { A. } \\
\%\end{array}$ & $\begin{array}{l}\mathrm{N} . \\
\%\end{array}$ & $\begin{array}{l}\text { D } \\
\%\end{array}$ & $\begin{array}{l}\text { S. D } \\
\%\end{array}$ & $\%$ \\
\hline 1 & We Consider guest as a god & $\begin{array}{l}223 \\
35.97 \%\end{array}$ & $\begin{array}{l}169 \\
27.26 \%\end{array}$ & $\begin{array}{l}127 \\
20.48 \%\end{array}$ & $\begin{array}{l}60 \\
9.68 \%\end{array}$ & $\begin{array}{l}41 \\
6.61 \%\end{array}$ & 100 \\
\hline 2 & $\begin{array}{l}\text { Our village has good } \\
\text { potential to attract tourists }\end{array}$ & $\begin{array}{l}250 \\
40.32 \%\end{array}$ & $\begin{array}{l}151 \\
24.35 \%\end{array}$ & $\begin{array}{l}98 \\
15.81 \%\end{array}$ & $\begin{array}{l}71 \\
11.45 \%\end{array}$ & $\begin{array}{l}50 \\
8.06 \%\end{array}$ & 100 \\
\hline 3 & $\begin{array}{l}\text { Our traditions and culture } \\
\text { are different from other } \\
\text { village offering CBT }\end{array}$ & $\begin{array}{l}114 \\
18.39 \%\end{array}$ & $\begin{array}{l}198 \\
31.94 \%\end{array}$ & $\begin{array}{l}93 \\
15.00 \%\end{array}$ & $\begin{array}{l}124 \\
20.00 \%\end{array}$ & $\begin{array}{l}91 \\
14.68 \%\end{array}$ & 100 \\
\hline 4 & $\begin{array}{l}\text { We provide good ambience } \\
\text { to the tourists }\end{array}$ & $\begin{array}{l}208 \\
33.55 \%\end{array}$ & $\begin{array}{l}169 \\
27.26 \%\end{array}$ & $\begin{array}{l}107 \\
17.26 \%\end{array}$ & $\begin{array}{l}76 \\
12.26 \%\end{array}$ & $\begin{array}{l}60 \\
9.68 \%\end{array}$ & 100 \\
\hline 5 & $\begin{array}{l}\text { We take care well of } \\
\text { cleanliness and hygiene }\end{array}$ & $\begin{array}{l}181 \\
29.19 \%\end{array}$ & $\begin{array}{l}302 \\
48.71 \%\end{array}$ & $\begin{array}{l}52 \\
8.39 \%\end{array}$ & $\begin{array}{l}50 \\
8.06 \%\end{array}$ & $\begin{array}{l}35 \\
5.65 \%\end{array}$ & 100 \\
\hline 6 & $\begin{array}{l}\text { We offer unique experience } \\
\text { to tourists }\end{array}$ & $\begin{array}{l}199 \\
32.10 \%\end{array}$ & $\begin{array}{l}220 \\
35.48 \%\end{array}$ & $\begin{array}{l}79 \\
12.74 \%\end{array}$ & $\begin{array}{l}60 \\
9.68 \%\end{array}$ & $\begin{array}{l}62 \\
10.00 \%\end{array}$ & 100 \\
\hline 7 & $\begin{array}{l}\text { We have home stay for } \\
\text { tourists in our own village }\end{array}$ & $\begin{array}{l}294 \\
47.42 \%\end{array}$ & $\begin{array}{l}189 \\
30.48 \%\end{array}$ & $\begin{array}{l}76 \\
12.26 \%\end{array}$ & $\begin{array}{l}40 \\
6.45 \%\end{array}$ & $\begin{array}{l}21 \\
3.39 \%\end{array}$ & 100 \\
\hline 8 & $\begin{array}{l}\text { We can easily handle } \\
\text { tourists and offer various } \\
\text { facilities }\end{array}$ & $\begin{array}{l}132 \\
21.29 \%\end{array}$ & $\begin{array}{l}186 \\
30.00 \%\end{array}$ & $\begin{array}{l}86 \\
13.87 \%\end{array}$ & $\begin{array}{l}124 \\
20.00 \%\end{array}$ & $\begin{array}{l}92 \\
14.84 \%\end{array}$ & 100 \\
\hline
\end{tabular}

First of all, respondents were asked about the conception of guest as a good, out of the total respondents $35.97 \%$ were strongly agree. $27.26 \%$ agreed, $20.48 \%$ neither agree nor disagree, $9.68 \%$ disagree, $6.61 \%$ disagree. Results show the positive perception of the community.

Next statement was about to the village potential to attract the visitors. In this regard, $40.32 \%$ were strongly agreed following $24.35 \%$ agree, $15.81 \%$ neutral, $11.45 \%$ disagree, $8.06 \%$ strongly disagree. Maximum respondents pointed out that their village has good potential to attraction to attract the visitors.

For the question of traditions and culture uniqueness, $18.369 \%$ respondents were strongly agreed while $31.94 \%$ agree following $15 \%$ neither agree nor disagree, $20 \%$ disagree, $14.68 \%$ strongly disagree. The result shows that almost $50 \%$ of people agree with the fact of uniqueness of traditions and approximately $35 \%$ were disagreed. The results show a little negative perception of people this is because in Garhwal reason known for the similar traditions but a small difference noticed in traditions. 
Moreover, again statement is very important and necessary for the tourism because ambience plays a very prominent role to attract visitors. For this question, $33.55 \%$ respondents were strongly agreed, $27.26 \%$ agree, $17.26 \%$ neither agree nor disagree, $12.26 \%$ disagree while $9.68 \%$ strongly disagree with the fact that they provide good ambience to visitors. The result shows that maximum numbers of $(60.81 \%)$ were agreed with the fact they provide good ambience.

Additionally, when the local people asked about the hygiene and cleanliness $29.19 \%$ were strongly agreed, $48.71 \%$ agree, $8.39 \%$ neutral, $8.06 \%$ disagree, $5.65 \%$ strongly disagree. Overall perception indicates that people maintain cleanliness of the destination as approximately $77 \%$ people agree with fact that local people take care well of cleanliness.

In every sector, tourists' satisfaction is a considerable factor for the service provider and similarly tourists' satisfaction matters for the community of a destination. To answer the question of unique experience $32.10 \%$ strongly agree, $35.48 \%$ agree, $12.74 \%$ neutral while a little percentage $(9.68 \%)$ disagreed and $10.00 \%$ were strongly disagreed.

Home stay is the very essential component of the community-based tourism because the foremost aim of CBT provides homely environment to the visitors and that is not possible in hotels and lodges. A large number of respondents were strongly agreed while a very little percentage $(6.45 \%)$ disagreed, $3.39 \%$ strongly disagree with the availability of home stay. So, the overall response to the home stay is positive.

Apart from above mention tourism resources other resources are also important to develop the tourism of a destination and the management as well as handling of those resources is a difficult task for the community but for the answer to this question $21.29 \%$ strongly agree, $30.00 \%$ agree, $13.87 \%$ neither agree nor disagree while $20.00 \%$ disagree and $14.84 \%$ strongly disagree. The perception about the handling various facilities related to tourism is positive up to large extent. Almost $35.00 \%$ respondents were not agreed with the fact. That is a negative indication for CBT. Community members find very hard in managing of tourism products due to the lack of training, skill development and learning. Although the perception of communities, for the fact of traditions, uniqueness, handling of tourism products are a bit negative but overall perception is positive that is very helpful and important to develop as well as enhance CBT in Chamoli district.

The mean and standard values related to the potential components for CBT is presented in Table 2.

Table No. 2: Mean Values of Potential Components for CBT

\begin{tabular}{|c|c|c|c|c|}
\hline \multicolumn{5}{|c|}{ Potential Components for Community Based Tourism } \\
\hline S. $\mathbf{N}$. & Question & Mean & Std. Dev. & Rank \\
\hline 1. & Our village has good potential to attract tourists & 4.43 & 0.52 & 1 \\
\hline 2. & $\begin{array}{l}\text { Our traditions and culture are different from other } \\
\text { village offering CBT }\end{array}$ & 4.34 & 0.76 & 2 \\
\hline 3. & We consider guest as a god & 4.27 & 0.54 & 3 \\
\hline 4. & We have home stay for tourists in our own village & 4.27 & 0.71 & 4 \\
\hline 5. & We take care well of cleanliness and hygiene & 4.22 & 0.58 & 5 \\
\hline 6. & We provide good ambience to the tourists & 3.98 & 0.69 & 6 \\
\hline 7. & We offer unique experience to tourists & 3.97 & 0.64 & 7 \\
\hline 8. & We can easily handle tourists and offer various facilities & 3.45 & 0.73 & 8 \\
\hline
\end{tabular}

On the basis of mean value, these components have been ranked. The maximum value is (4.43) for the potential of CBT in village following (4.34) for the uniqueness of traditions and customs, consider guest as a god (4.27), home stay facility (4.27), hygiene (4.22), ambience (3.98), provide unique experience to 
visitors (3.97), handling of tourism resources (3.45). Hence, 4.43 is the highest mean value while 3.45 is the lowest mean value.

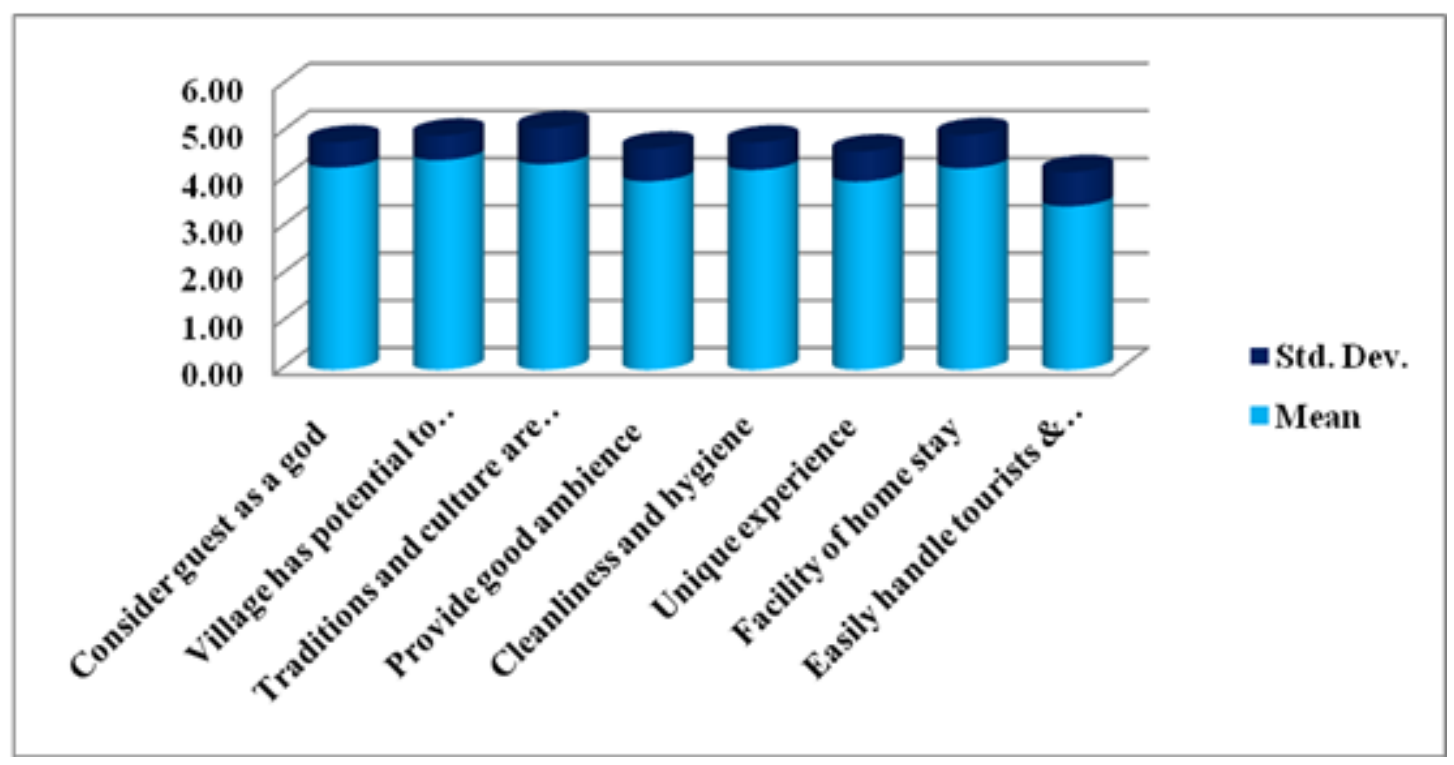

Figure2: Mean Values for Potential Components of CBT (Source: Compiled by Researcher)

On the basis of mean values, village has good potential to attract visitors get the highest rank following traditions and culture are different from other villages, consider the guest as a god, home stay facility, cleanliness and hygiene, ambience, offer a unique experience and easily handle tourists and tourism resources gets the lowest rank.

The gender wise perception of respondents related data is presented in Tale 3 which shows that in case of male and female respondents of Chamoli district, female respondents obtained less mean score $(m=33.94)$ in comparison to male respondents $(m=34.00)$. The $t$-value is found to not significant at 0.05 level of significance for $\mathrm{df} 618$, the reason is that the calculated value t-value (0.89) is lower than the table value (1.98). Hence, the hypothesis of Independent sample t-test says that 'There is no significant difference between male and female perception about the potential components of CBT'stands to be accepted at significance level of 0.05 .

Table: 3 Gender wise Perception of Respondents

\begin{tabular}{|l|c|c|c|c|c|c|c|}
\hline & $\mathrm{N}$ & Mean & SD & SEM & df & t -value & Significant \\
\hline Female & 250 & 33.94 & 3.83 & 0.34 & \multirow{2}{*}{618} & 0.89 & NS \\
\hline Male & 370 & 34.00 & 4.04 & 0.27 & & & \\
\hline
\end{tabular}

Difference between the unemployed and employed respondents' perception mean, $\mathrm{SD}$, t-value is shown in Table 4 which shows that in case of employed and unemployed respondents of Chamoli district, unemployed respondents obtained less mean score $(\mathrm{m}=33.9)$ in comparison to employed respondents $(\mathrm{m}=34.07)$. The $\mathrm{t}$-value is found to not significant at 0.05 level of significance for $\mathrm{df} 618$, the reason is that calculated value t-value $(0.78)$ is lower than the table value (1.98). Hence, the hypothesis of Independent sample t-test says that 'There is no significant difference between employed and unemployed respondents' perception about the potential components of $C B T$ ' stands to be accepted at significance level of 0.05

Table: 4 Employment Status wise Perception of Respondents 


\begin{tabular}{|c|c|c|c|c|c|c|c|}
\hline & $\mathrm{N}$ & Mean & SD & SEM & df & t-value & Significant \\
\hline Unemployed & 190 & 33.9 & 4.06 & 0.35 & \multirow{2}{*}{618} & \multirow{2}{*}{0.78} & NS \\
\hline Employed & 430 & 34.07 & 4.03 & 0.27 & & & \\
\hline
\end{tabular}

Difference between the married and unmarried respondents' perception is shown in the Table $\mathbf{5}$ which shows that in case of married and unmarried respondents of Chamoli district, married respondents obtained less mean score $(m=33.85)$ in comparison to unmarried respondents $(m=34.42)$. The $t$-value is found to not significant at 0.05 level of significance for $\mathrm{df} 618$, the reason is that calculated value $\mathrm{t}$-value (0.264) is lower than the table value (1.98). Hence, the hypothesis of Independent sample t-test says that 'There is no significant difference between married and unmarried respondents' perception about the potential components of $C B T$ ' stands to be accepted at significance level of 0.05 .

Table: 5 Marital Status wise perceptionsof Respondents

\begin{tabular}{|c|c|c|c|c|c|c|c|}
\hline & $\mathrm{N}$ & Mean & SD & SEM & df & t-value & Significant \\
\hline Married & 425 & 33.85 & 3.94 & 0.24 & \multirow{2}{*}{348} & \multirow{2}{*}{0.264} & \multirow{2}{*}{ NS } \\
\cline { 1 - 4 } Unmarried & 195 & 34.42 & 3.99 & 0.45 & & & \\
\hline
\end{tabular}

\section{Conclusion:}

To conclude the study it can be said that there is a vast potential to develop the CBT in Chamoli district. The results show that study area is full of components that supports the CBT and enhance the tourism products. The mean value for each component is higher than 3 that show the high intensity of every component. Apart from this, each group of respondents has similar perception for the CBT components. Thus, the residents' perception is very encouraging that pave the way to develop the CBT in the Chamoli district.

\section{References}

Chapman, M., \& Kirk, K. 2001. Lessons for Community Capacity Building: A summary of the research evidence. Retrieved 2, October, 2007, from http://www.scot-homes.gov.uk/pdfs/pubs/260.pdf

Folke, C., Carpenter, S., Elmqvist, T., Gunderson, L., Holling, C. S., \& Walker, B. 2002. Resilience and sustainable development: Building adaptive capacity in a world of transformations. Ambio, 31(5), 437-440.http://dx.doi.org/10.1639/0044-7447(2002)031[0437:Rasdba]2.0.Co;2.

Gupta and Bhatt

Hai, M. A., \& Chik, A. R. 2011. Political stability: Country image for tourism industry in Bangladesh. Paper presented at the Proceeding of the International Conference on Social Science, Economics and Art 2011, Hotel Equatorial Bangi-Putrajaya, Malaysia.

Hall, D. R., Kirkpatrick, I., \& Mitchell, M. (Eds.). 2005. Rural Tourism and Sustainable Business: Channel View Publications.

Haque, A. K. E., \& Aich, D. 2014. Economic valuation of ecosystem services in Bangladesh Sundarban Delta Vision 2050 - A first step in its formulation. Retrieved from Bangladesh Country Office, Dhaka.

Hasan, A. 2012. 'Package eco-tour' as special interest tourism product-Bangladesh perspective. Developing Country Studies, 2(1), 1-9.

Honey, M. 2008. Ecotourism and sustainable development: Who owns paradise? (2nd ed.). Washington DC, USA: Island Press. 
Iqball, M. S., Parvin, M., Salekuzzaman, M., Haque, S. E., Islam, M. R., \& Ahmed, M. S. 2010. Ecotourism in Sundarbans and its surrounding- A possible sustainable option for alternative livelihood development. Bangladesh Research Publications Journal, 4(3), 244 253.http://dx.doi.org/10.5772/55749.

Mallya, A. 2006. Wildlife tourism and conservation. Dehli, India: Gnosis Publisher.

Walker, B., Carpenter, S., Anderies, J., Abel, N., Cumming, G. S., Janssen, M., Lebel, L., Norberg, J., Peterson, G. D., \& Pritchard, R. 2002. Resilience management in social-ecological systems: a working hypothesis for a participatory approach. Conservation Ecology, 6(1). http://dx.doi.org/WOS:000177892600018.

Wightm, P. A. 1996. North American ecotourism markets: motivations, preferences and destinations. Journal of Travel Research, 34(2), 3-10. http://dx.doi.org/10.1177/004728759603500102.

WTO. (2000). WTO news (2nd quarter 2000 Issue 2). Retrieved from Madrid, Spain. 